\author{
Alidor Busanga Kankonda*, Isaac \\ Ekyamba Shabani, Jacob Nsila Ndjaki, \\ Consolate Kaswera, Ernest Lukosha \\ Tambwe and Alain Bolonga Bolonga \\ Department of Hydrobiology and Aquaculture, \\ University of Kisangani, PO Box: 2012, Kisangani, \\ DR Congo, Africa \\ Dates: Received: 13 February, 2016; Accepted: 08 \\ March, 2016; Published: 10 March, 2016 \\ *Corresponding author: Kankonda Busanga Alidor, \\ Department of Hydrobiology and Aquaculture, \\ University of Kisangani, BP 2012, Kisangani, DR \\ Congo, Africa, Tel: +243-81-39-86-632; E-mail: \\ kankonda2000@yahoo.fr \\ www.peertechz.com \\ ISSN: $2455-8400$ \\ Keywords: Diet; Reproduction; Seasonal periods: \\ Stomatorhinus cf polli; Masendula stream
}

\section{Research Article \\ Preliminary Data on Biology of Stomathorinus Cf Polli Matthes, 1964 of Masendula Stream (Kisangani, RD Congo)}

\begin{abstract}
Background and aim: Stomatorhinus cf polli, one of species of Mormyridae whose flesh is highly appreciated by local communities. Unfortunately, there is very little information about biology and ecology of Stomatorhinus cf polli. This study aimed to determine the ecology and biology of Stomathorinus cf polli.

Methods: The circular dip scoop net of $0.5 \mathrm{~mm}$ of mesh and the amplifier were used during twelve months. 260 specimens of Mormyridae were collected in a single site of Masendula stream. All fish samples were weighed using scales, as well as each fish were measured using a tape measure and caliper. Diet and reproduction were analyzed.

Results: The analysis of 151 stomach contents of Stomatorhinus cf polli allowed identifying three prey categories (animal detritus, vegetable detritus and chironomidae). The diet of Stomatorhinus cf polli expressed in the coefficient of occurrence showed that individuals feed the same prey but in different proportions. The mean intestinal coefficient calculated for specimens of Stomatorhinus cf polli is 0.58 . This species prefers more to consume animal detritus. For reproduction, the findings showed that this species breeds throughout the year. The mean relative fecundity is 25,125 oocytes per $\mathrm{kg}$.
\end{abstract}

\section{Introduction}

Mormyridae are one of the largest fish groups of the Masendula stream. Although many publications and other works have been focused on their systematics [1,2], but there are few works on their reproduction and diet $[3,4]$. The study of the diet by stomach content analysis allows to solve primarily the issue of food resources in a qualitative and quantitative way, understand if in natural environments, the diverse species of the same group have an individualized diet or not and compare food relations existing between the species studied. This involves the concept of ecological niche as well as food specialization of Stomathorinus of polli (Figure 1).

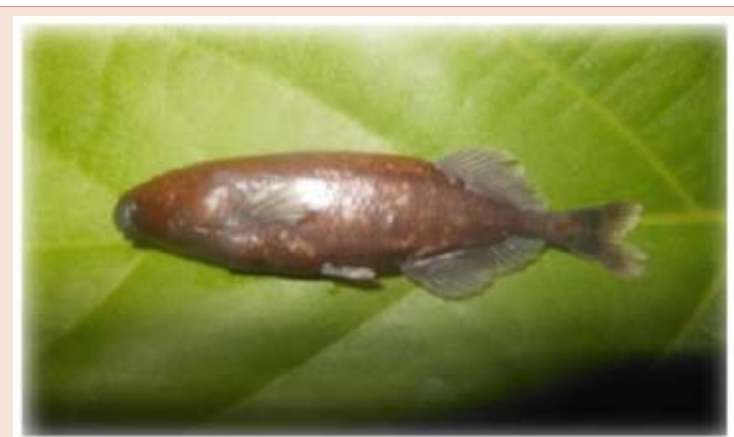

Figure 1: Stomathorinus cf polli.
Analysis carried out here intended typically to answer to three fairly key questions:

- What is the specific diversity of Mormyridae of Masendula stream?

- What is the food biology of Stomathorinus cf polli?

- At what seasonal period this species breeds?

\section{Overall objective}

This study aimed to inventory of Mormyridae of Masendula stream and to determine the ecology and biology of Stomathorinus cfpolli.

\section{Specific objectives}

- To determine the specific diversity of Mormyridae of Masendula stream;

- To know the food biology of Stomathorinus cf polli;

- To master the seasonal period of reproduction of Stomathorinus cf polli.

\section{Material and Methods}

\section{Study area}

The Masendula stream is located in the middle basin of the Congo River.

It is a tributary of River Tshopo in its lower basin. It has a climate 


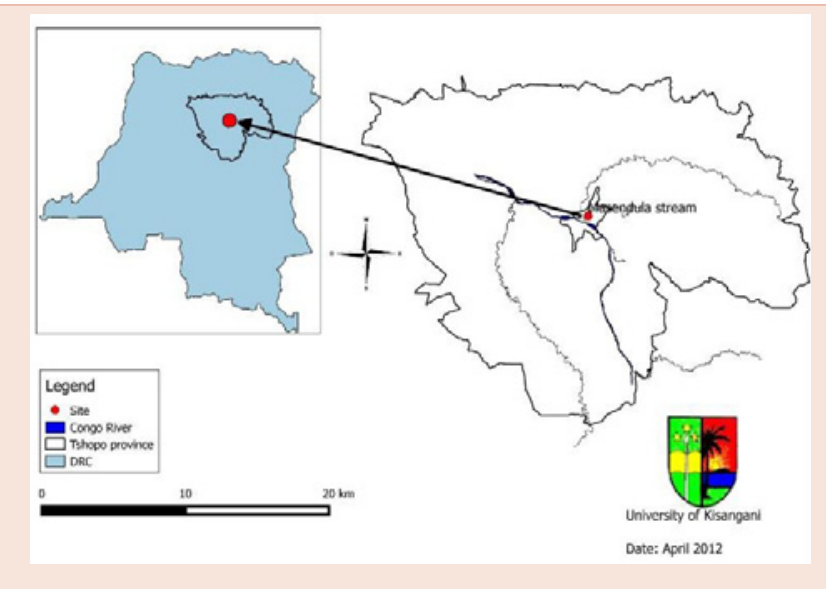

Figure 2: Map showing the sampling site.

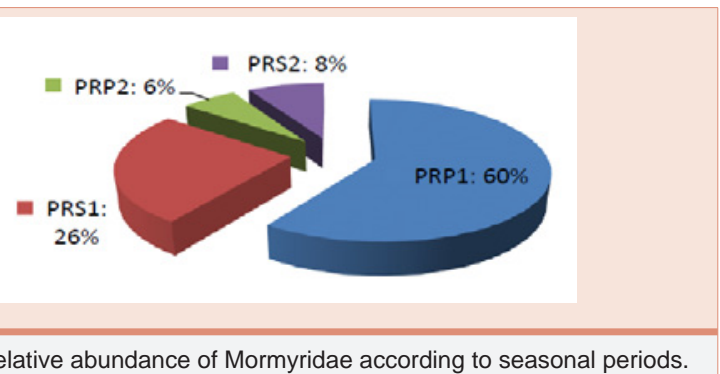

Figure 3: Relative abundance of Mormyridae according to seasonal periods.

that belongs in the Af type (hot and humid climate with an average temperature of the coldest month higher than $18^{\circ} \mathrm{C}$ and a rainfall distributed over the year) of the classification of Köppen-Trewartha [5]. The stream stretch investigated is entirely in the secondary forest zone and extends between $0^{\circ} 34^{\prime} 27.3^{\prime \prime}$ and $0^{\circ} 34^{\prime} 60.9^{\prime \prime} \mathrm{N}$ latitude and between $25^{\circ} 13^{\prime} 24.2^{\prime \prime}$ and $25^{\circ} 13^{\prime} 59.1^{\prime \prime}$ E longitude.

The mean values of physico-chemical properties of water in the sampling site: water temperature $\left(23.61 \pm 1.05^{\circ} \mathrm{C}\right)$, dissolved oxygen (7.51 $\pm 2.56 \mathrm{mg} / \mathrm{l}), \mathrm{pH}(5.63 \pm 1.65)$, conductivity $(65.65 \pm 16.73 \mu \mathrm{s} / \mathrm{cm})$, water depth $(0.68 \pm 0.12 \mathrm{~m})$ and water velocity $(0.43 \pm 0.13 \mathrm{~m} / \mathrm{s})$ [6], (Figure 2).

\section{Sampling procedure}

The amplifier of Archer mark was used to detect the presence of mormyrid fishes before the catch by using a circular dip scoop net of $0.5 \mathrm{~mm}$ of mesh. 260 specimens of Mormyridae were collected from March 2011 to February 2012 in a single site (Masendula stream) during twelve sessions of collecting data; therefore one session per month. Captured fish were injected the formaldehyde $10 \%$ in order to stop the digestion process and were preserved in $70 \%$ ethanol and then transported to laboratory of Hydrobiology and Aquaculture for further analyses.

All fish samples were weighed using scales of Sartorius mark with a precision nearest $0.01 \mathrm{~g}$, Kerne and Stalter marks with a precision nearest $0.1 \mathrm{~g}$ as well as Stanley mark. The total length (LT) and standard length (SL) of each fish were measured using a tape measure and calliper.

\section{Analysis methods of stomach contents and sexual maturity}

The occurrence method was used in order to count the number of stomachs in which a prey or a prey category is present. If $\mathbf{n}$ is the number of stomachs containing a prey category and $\mathbf{N}$ is the total number of examined stomachs. The results are expressed as a percentage of total number of inventoried stomachs. \% Occ $=n \times 100$ / $N$ [7-11].

This method gives a good idea of food preferences for the fish, but does not provide the indication on the quantitative importance of ingested prey.

To determine the food preferences for this abundant species, the classification of Chikou et al. [12] and Lausane [7], have been adopted:

- Preferred prey: \% Occurrence $>50 \%$.

- Secondary prey: $10 \leq \%$ Occurrence $\leq 50 \%$.

- Accidental prey: \% Occurrence $\leq 10 \%$.

Relative length of intestine, relative weight of stomach and condition factor $\mathrm{K}$ were determined according to the methods described by Biswas [13].

Maturity stages and fecundity were estimated according to Philippart [14].

\section{Data analysis}

Statistical analyses were performed using Microsoft Excel 2010. The correlation coefficients between weight of fish (g) and fish size $(\mathrm{cm})$, and gonad weight $(\mathrm{g})$, weight of fish and absolute fecundity and finally absolute fecundity and size of fish were calculated.

The similarity index was used in order to compare the diet depending on the size classes on the basis presence / absence of prey [15]. The similarities of diet between the size classes within this species were identified through the hierarchical ascending classification analysis "cluster analysis". Biodiv. MVSP (Multi Variate Statistical Package) software was used to calculate this similarity.

\section{Results}

A total of 260 specimens of Mormyridae were sampled belonging to three species including Stomatorhinus cf polli with 151 individuals (or 58\%), Pollumirus of fasciolatus with 79 specimens (or 30\%) and Gnathonemus petersii with 30 individuals (or 12\%).

\section{Relative abundance of mormyridae according to seasonal periods}

Legend: PRP1 = rainy season 1 (March to May), PRS1 = relatively dry season 1(June to August), PRP2 = rainy season 2 (September to November), PRS2 = relatively dry season 2 ((December to February).

Figure 3 shows that the relative abundance of Mormyridae was highest during the rainy season 1 with $60 \%$ of individuals.

\section{Abundance distribution of species by seasonal periods}

Figure 4 shows that the capture was important during rainy 
- Stomatorhinus cf polli $\quad$ Gnathonemus petersii a Pollumirus cf fasciolatus

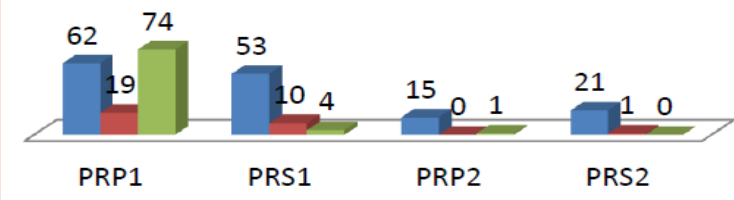

Figure 4: Abundance distribution of species depending on seasonal periods.

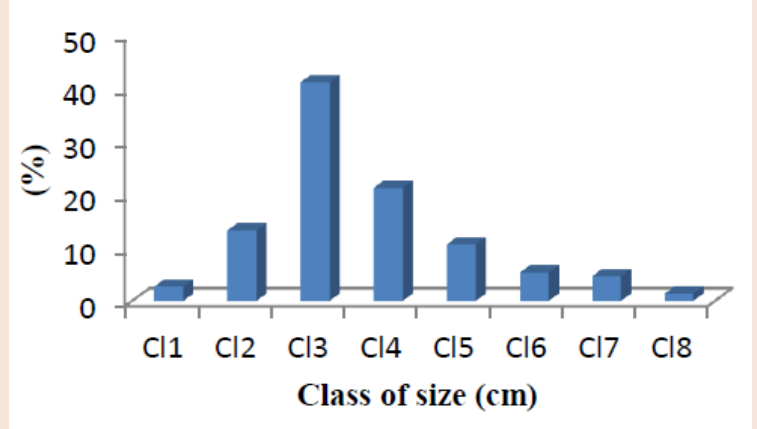

Figure 5: Size structure of Stomatorhinus cf polli according to the standard length.

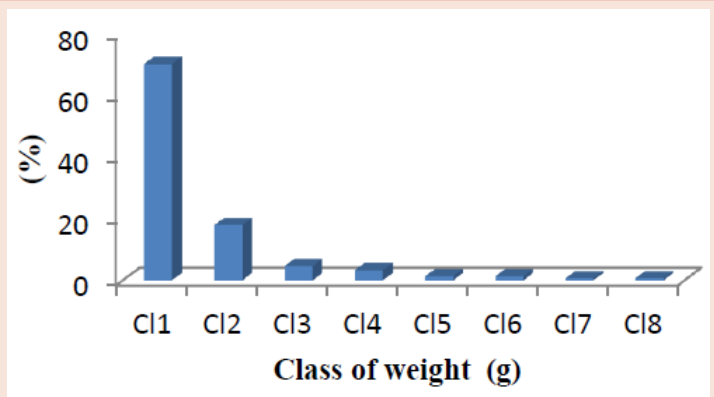

Figure 6: Weight structure of Stomatorhinus cf polli.

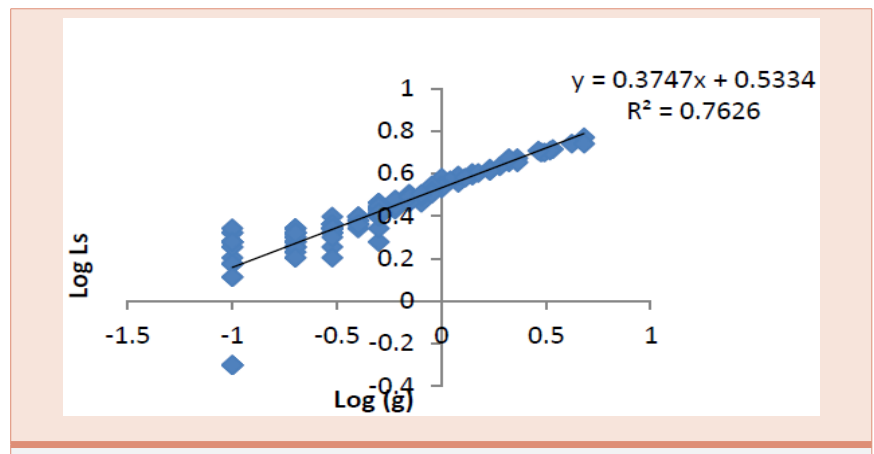

Figure 7: Relationship between the size and weight of Stomatorhinus cf polli.

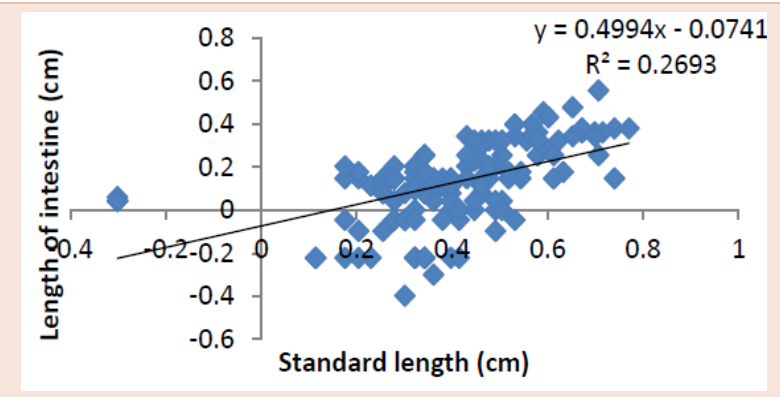

Figure 8: Diagram of relationship between length of intestine and standard length of Stomatorhinus cf polli.

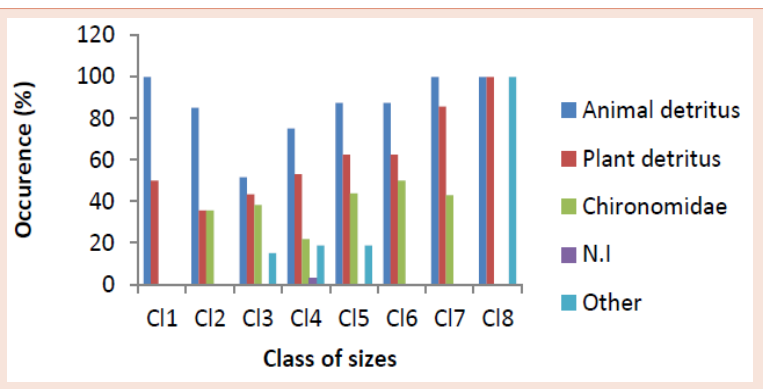

Figure 9: Distribution of categories of prey depending on size.

season 1 for Pollumyrus of fasciolatus with 74 individuals followed by Stomathorinus of polli with 62 individuqls. Other seasonal periods (PRS1, PRP2 and PRS2), the catches have been important to Stomathorinus cf polli with 53,15 and 21 specimens respectively.

\section{Size structure of Stomathorinus cf polli}

151 specimens of Stomathorinus cf polli with standard length that varies from 0.5 to $6.1 \mathrm{~cm}$ were included into 8 classes with the interval of $0.7 \mathrm{~cm}$.

Figure 5 shows that the class 3 is the most abundant with $41.05 \%$ followed by class 4 with $21.19 \%$ while the lowest is the class 8 with $1.32 \%$.

\section{Weight structure}

151 individuals of Stomatorhinus cf polli with the weight of body varies from 0.1 to $4.9 \mathrm{~g}$ were included into 8 classes with the interval $0.6 \mathrm{~g}$.

Figure 6 shows that class 1 is the highest with $70.19 \%$ followed by class 2 with $17.88 \%$.

Relationship between the size and weight of Stomatorhinus cf polli

Figure 7 summarizes the relationship between the size and weight of specimens of Stomatorhinus cf polli. The growth is allometric $(\mathrm{b}=$ 0.3747 ) with predominance by weight which the correlation with size is significant $\left(r^{2}=0.7626\right)$. 


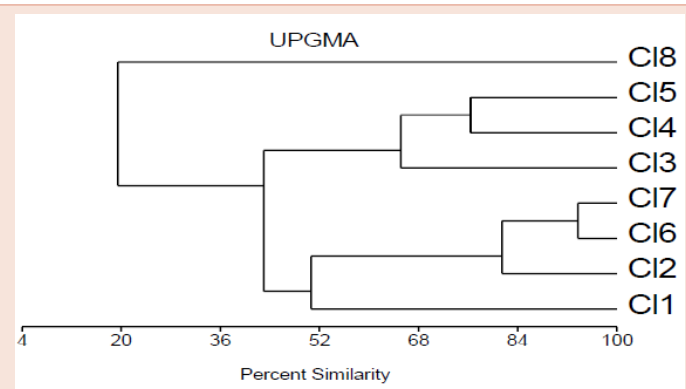

Figure 10: Euclidean similarity dendrogram.

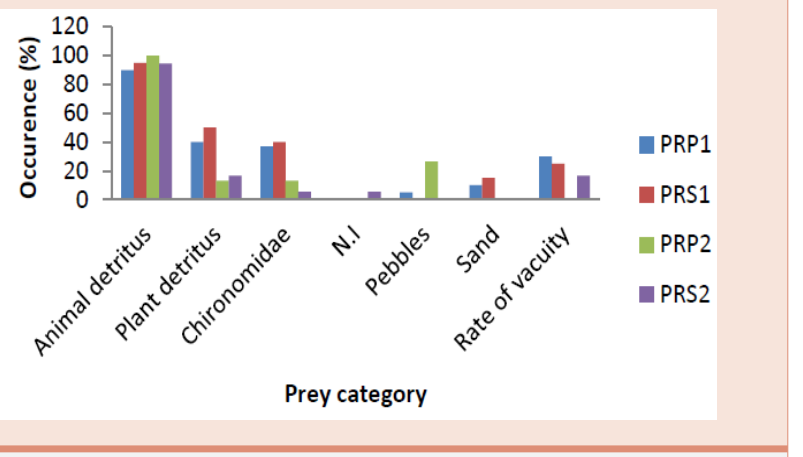

Figure 11: Change in the main food according to seasonal periods.

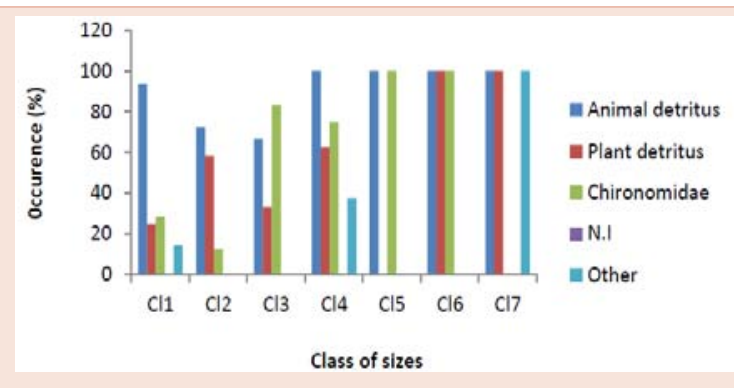

Figure 12: Distribution of prey categories depending on size classes during rainy season.

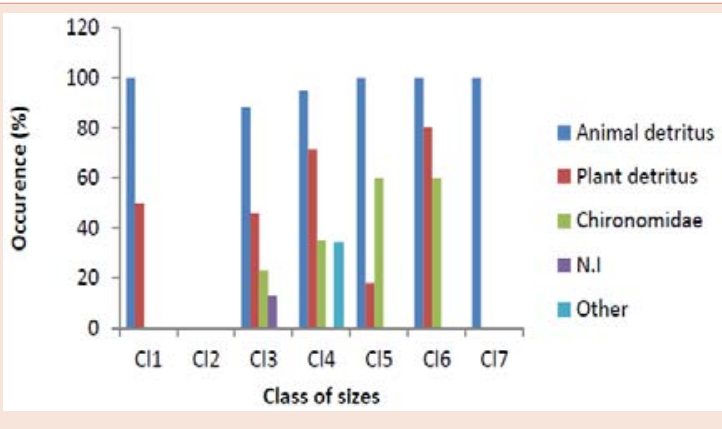

Figure 13: Distribution of prey categories depending on size classes during relatively dry season.
Table 1: Prey categories, frequency (n), percentage of occurrence (\% Occ) and rate of vacuity (CV) of Stomatorhinus cf polli caught in the Masendula River.

\begin{tabular}{|l|c|c|}
\hline Prey category & Frequency $(\mathbf{n})$ & \% occ. \\
\hline Animal detritus & 87 & 79.09 \\
\hline Chironomidae & 38 & 34.54 \\
\hline $\mathrm{NI}$ & 1 & 0.9 \\
\hline Plant detritus & 55 & 50 \\
\hline Other & & \\
\hline Pebbles & 7 & 6.36 \\
\hline Sand & 9 & 8.18 \\
\hline Rate of vacuity & NES $=41$ & RV $=37.27 \%$ \\
\hline
\end{tabular}

Occ = occurrence, $\mathrm{Nl}=$ unidentified, NES = number of empty stomachs, $\mathrm{RV}=$ rate of vacuity.

\begin{tabular}{|l|l|l|l|l|}
\hline \multicolumn{4}{|l|}{ Table 2: Percentage of similarity index. } \\
\hline Node & Group 1 & Group 2 & Simil. & Group \\
\hline 1 & Cl6 & Cl7 & 93.75 & 2 \\
\hline 2 & $\mathrm{Cl} 2$ & Node 1 & 81.579 & 3 \\
\hline 3 & $\mathrm{Cl} 1$ & $\mathrm{Cl}$ & 76.404 & 2 \\
\hline 4 & $\mathrm{Cl}$ & Node 3 & 65.142 & 3 \\
\hline 5 & $\mathrm{Cl} 1$ & Node 2 & 50.649 & 4 \\
\hline 6 & Node 5 & Node 4 & 43.063 & 7 \\
\hline 7 & Node 6 & Cl8 & 19.376 & 8 \\
\hline
\end{tabular}

\section{Diet of Stomatorhinus cf polli}

Relationship between length of intestine and standard length

There exists significant linear functional relationship between length of intestine and standard length of Stomatorhinus of polli as shown in the Figure 8.

The correlation between length of intestine and standard length is slightly significant $\left(r^{2}=0.2693\right.$ and $\left.r=0.5189\right)$. The growth of intestine is depending on length of fish.

Overall quality diet of Stomatorhinus cf polli

Table 1 shows the categories of prey consumed by Stomatorhinus cf polli, their coefficient of occurrence and their coefficient of emptiness for the set of analysed stomachs.

By analysing the overall composition of food and calculated occurrences, we find that the food preference of Stomatorhinus cf polli is mainly from animal origin. The animal detritus was highest consumed with $79.09 \%$ followed by vegeTable detritus with $50 \%$ and Chironomidae with $34.54 \%$.

Figure 9 shows that the individuals of different classes of size feed on the same prey but in different proportions. Note that the occurrence of plant detritus seems to increase with fish size.

\section{Euclidean similarity index and morista distance of diet according to size classes}

Figure 10 and Table 2 indicate the information on the degree of similarity of diet between the size classes of Stomatorhinus cf polli.

Figure 10 and Table 2 clearly reveal that:

- Ascending classification established between changes in the 
Table 3: Average values of relative weight of stomachs and coefficient $\mathrm{K}$ to each seasonal period.

\begin{tabular}{|l|l|l|l|l|}
\hline Seasonal period & PRP1 & PRS1 & PRP2 & PRS2 \\
\hline Number of stomachs & 62 & 53 & 15 & 21 \\
\hline $\begin{array}{l}\text { Average relative } \\
\text { weight (g) }\end{array}$ & $0.0186 \pm 0.293$ & $0.1157 \pm 0.340$ & $0.007 \pm 0.45$ & $0.003 \pm 0.25$ \\
\hline Condition factor (K) & $0.3558 \pm 0.596$ & $0.3564 \pm 0.597$ & $0.15 \pm 0.79$ & $0.28 \pm 2.48$ \\
\hline
\end{tabular}

Table 4: Standard length (Ls), average number of oocytes and average weight of gonads of females (Pgo) of Stomatorhinus cf polli to the maturity stages of $3 / 4$ and $4 / 4$.

\begin{tabular}{|c|c|c|c|c|}
\hline & Parameter & Min & Mean \pm SD & Max \\
\hline & Ls (cm) & 4.7 & $4.95 \pm 2.22$ & 5.2 \\
\hline & Oocytes & 60 & $87 \pm 9.33$ & 114 \\
\hline \multirow[t]{4}{*}{ PRP1 } & Pgo (g) & 0.11 & $0.07 \pm 0.26$ & 0.33 \\
\hline & Relative fecundity & 26,090 & $30,220 \pm 173.84$ & 33,530 \\
\hline & Ls (cm) & 4.2 & $4.7 \pm 2.17$ & 5.1 \\
\hline & Oocytes & 45 & $68 \pm 8.25$ & 96 \\
\hline \multirow[t]{4}{*}{ PRS1 } & Pgo (g) & 0.02 & $0.06 \pm 0.24$ & 0.13 \\
\hline & Relative fecundity & 19,570 & $17,560 \pm 132.51$ & 33,100 \\
\hline & Ls & 2.5 & $2.7 \pm 0.13$ & 2.9 \\
\hline & Oocytes & 45 & $159 \pm 68,25$ & 273 \\
\hline \multirow[t]{4}{*}{ PRP2 } & Pgo & 0.01 & $0.03 \pm 0.013$ & 0.05 \\
\hline & Relative fecundity & 11,250 & $25,125 \pm 9,250$ & 39,000 \\
\hline & Ls & 2.8 & $3.9 \pm 0.73$ & 5 \\
\hline & Oocytes & 60 & $63 \pm 2$ & 66 \\
\hline \multirow[t]{2}{*}{ PRS2 } & Pgo & 0.06 & $0.06 \pm 0.003$ & 0.07 \\
\hline & Relative fecundity & 10,000 & $15,645 \pm 2,623$ & 21,290 \\
\hline
\end{tabular}

diet of Stomatorhinus of polli allowed to note similarities among the different size classes;

- Class 6 shows more similarity with class 7 (or 93.75\%). However the class 2 indicates more affinity with classes 6 and 7 (Node 1) of $81.58 \%$;

- Class 4 shows more similarity with class 5 (or 76.4\%) while class 3 reports more affinity with the classes 4 and 5 (Node 3) of $65.14 \%$.

\section{Diet quality according to the seasonal periods}

Figure 11 contains the values of occurrence index of food ingested by Stomatorhinus cf polli during seasonal periods.

Figure 11 shows that the animal detritus is essential prey in the diet of Stomatorhinus cf polli with higher percentage of occurrence. The highest rate of vacuity is observed in the rainy season 1 followed by seasonal periods relatively dry 1 and 2 .

\section{Diet quality according to size classes for the rainy season}

The values of intraspecific change in the diet of Stomatorhinus cf polli are reflected in the Figure 12.
Figure 12 shows that the animal detritus is abundant prey for all sizes, followed by the plant detritus and chironomidae.

\section{Diet quality according to the size for relatively dry season}

The values of intraspecific change in the diet of Stomatorhinus cf polli are reflected in the Figure 13.

Figure 13 shows clearly that animal detritus is abundant prey for all sizes, followed by pant detrituse and chironomidae.

\section{Influence of seasons on the relative weight of stomachs and condition coefficient}

Table 3 shows that the average relative weights of stomachs $(0.1157 \mathrm{~g})$ and condition factor $\mathrm{K}(0.3564)$ during the relatively dry season 1 are higher than those of other periods (PRP1, PRP2 and PRS2).

\section{Reproduction}

The results on mean absolute fecundity of Stomatorhinus cf polli are shown in the Table 4.

Table 4 shows that the high estimated relative fecundity is reported during the rainy season 2 with a minimum and maximum varying from 11,250 to 39,000 oocytes per $\mathrm{kg}$ with an average of 25,125 oocytes per $\mathrm{kg}$, followed by the rainy season 1 with a minimum and maximum oscillating from 26,090 to 33,530 oocytes per $\mathrm{kg}$ with an average of 30,220 oocytes.

\section{Ecology of Stomatorhinus cf polli}

According to the field observations relating to the micro-habitat of this species, we report that:

- It lives on benthic.

- It is more caught near bank in hollow place.

- It prefers water relatively quiet, heavily shaded dominated by aquatic vegeTable (Bambusa vulgaris) and its relatively slow.

\section{Discussion}

\section{Systematic inventory of mormyridae}

At total of 260 specimens of Mormyridae were collected belonging to three genera and three species which Stomatorhinus cf polli is the most abundant with $58 \%$. The method used for fishing is complementary but nevertheless insufficient in the assessment of diversity.

Teugels \& Guégan [16], mentioned that the family of Mormyridae is abundant in specific diversity. Indeed, we found that fishing net combined with the amplifier seems more appropriate to give very good results for fishing in stream. It would be complemented by other methods such as fishing to gillnets, creels, etc.

The findings show that the capture was highest during the rainy season 1 (Figure 2). That could be due to this seasonal period coincides with the reproduction of the most species of central basin. The dominance of Stomatorhinus cf polli on other species could be explained by the fact that this species finds optimal conditions of life 
in this stream including low change of physicochemical factors such as dissolved oxygen and temperature [17]. Matthes [18], indicated that this species operates the forest streams such as middle and small rivers and streams.

\section{Size and weight of Stomatorhinus cf polli}

Note that a difference to left of size and weight classes most represented while we thought to normal distribution. This could be explained by the low abundance of individuals [19], probably due to the collecting method low adapted for this species or the high exerted anthropogenic pressure on individuals with high size. White and Edwards [19], confirm that small sample will difficultly enable to estimate the probability distribution of data because there will not be the sufficient organization of graph.

The value of coefficient $b$ between weight and size of individuals is 0.37 with a slightly significant regression coefficient $\left(r^{2}=0.2669\right)$. This value shows that this species has an allometric growth against weight. Our results are similar to these found by Mahamba [19], in Yoko and Biaro forest streams (DRC) for Stomatorhinus corneti.

Relationship intestine length-standard length of Stomatorhinus cf polli

The findings show that the correlation value found between intestine length and standard length is significant $\left(r^{2}=0.76\right)$.

Several authors established a positive relationship between intestine and nature of food that consumed by fish. It is a useful index which gives an idea of nature of food [13].

From our study, the average intestine coefficient calculated is 0.58 .

Mahamba [20], reported an average intestine coefficient of 0.56 for Stomatorhinus cornet in Yoko and Biaro forest streams. Pigneur [21], worked on Marcusenius macrolepidotus angolensis, found an intestinal coefficient of 0.63 in Malebo stream (DRC). Mbimbi [22], indicated an average intestine coefficient of 0.54 for Marcusenius greshoffi in Kinshasa streams (DRC). Kouamélan [4] found at the Lake Ayamé Dam (Ivory Coast) for Marcusenius ussheri and M. furcidens an average intestine coefficient of 0.62 and 0.64 respectively.

\section{Diet}

Our results show that Stomathorinus of polli consume more animal detritus. The findings of Mahamba [20], on Stomathorinus corneti collected in Yoko and Biaro forest streams showed this species consumed more insects and crustaceans. Pingeur [21] and Mbimbi [22], found that genus Marcusenius consumed more animal and plant detritus in Malebo stream.

Our findings reported that there is no significant change depending on size and prey not consumed in similar proportions in all size classes. That would explain the influence of size on diet could be caused by size of prey to ingest proportionally to the size and the age of fish and could also be due to the seasonal periods. Animal detritus are preferred pry of this species during all seasonal periods and plant detritus remain secondary prey during all periods.

In the study of Traoré et al. [23], on feeding behavior depending on the size of fish, revealed that larvae of chironomidae are preferential prey of fish populations regardless of their size.

\section{Reproduction}

Fecundity can be defined as the most common measure of reproductive potential in fishes, because it is relatively easy to measure [24].

The minimum and maximum estimated fecundity of Stomathorinus cf polli varied 11,250 to 39,000 oocytes per kg with an average of 25,125 oocytes per kg. Kirschbaum [25], mentioned that several species of Mormyridae breed according to the raising of water level with lower conductivity.

\section{Conclusion}

This investigation was conducted at Masendula stream during one year. It was mainly focused on the ecology and biology of Stomathorinus of polli. 260 specimens of Mormyridae were collected by using a circular dip scoop net. The findings showed that Stomatorhinus of polli was the highest captured during the sampling with $58 \%$. The mean intestinal coefficient calculated is 0.58. It was observed Stomatorhinus of polli preferred more the animal detritus during all seasonal periods although other prey categories were identified into its stomach contents such as plant detritus, chironomidae, pebbles and sand. The results also show that Stomatorhinus of polli breeds throughout the year. The results indicated that the estimated fecundity of Stomathorinus $c f$ polli varied 11,250 to 39,000 oocytes per $\mathrm{kg}$ with an average of 25,125 oocytes per kg. Stomatorhinus of polli prefers water relatively quiet, heavily shaded dominated by Bambusa vulgaris.

The size of first maturity as well as diameter of oocytes should be also studied in order to complete the biological characteristics of this species.

\section{Acknowledgement}

The authors thank the authorities of Faculty of Sciences of University of Kisangani for their advices. Their thankful feelings are also addressed to the Department of Hydrobiology for the realization of this work.

\section{References}

1. Boden G, Teugels GG, Hopkins CD (1997) A systematic revision of the large-scaled Marcusenius with description of a new species from Cameroon (Teleostei; Osteoglossomorpha; Mormyridae). Journal of Natural History 31: 1645-1682.

2. Teugels GG, Boden G, Hopkins CD (2001) Morphological and electrophysiological evidence for synonymy of two Marcusenius species (Osteoglossomorpha, Mormyridae) from West Central Africa. Cybium 25: 239-249.

3. Ouattara M (2000) Reproduction strategies and reactions to environmental pressure to African fish. Mormyrops anguilloïdes et Marcusenius ussheri (Mormyridae), Schilbe mandibularis et S. intermedius (Schilbeidae). (Bia et Agnébi Basins, Côte d'Ivoire). Thesis. University of Abobo-Adjamé, Abidjan 266.

4. Kouamélan EP (1999) Effect of Ayamé dam lake (Côte d'Ivoire) on distribution and diet ecology of Mormyridae Teleostei, Ostéoglossiformes. Thesis. Katholieke Universiteit Leuven, Leuven, 221. 
5. Bultot F, Griffths JF (1972) The Equatorial Wet Zone. In World Survey of Climatology 10: Climates of Africa,edited by Griffiths JF Amsterdam-LondonNew York: Elsevier.

6. Nyongombe UNF (1993) Contribution to ecological and biological study of fishes from Masendula stream in Kisangani. Thesis. Institut Facultaire Agronomique/Yangambi, DRC 175.

7. Lauzanne $L$ (1975) Diet of Hydrocyon forskalii (Pisces, Characidae) in lake Tchad and its tributaries. Cahier ORSTOM, série. Hydrobiologie, 10: 105121.

8. Ulyel AP (1991) Diet ecology of Haplochromis spp (Teleostein: Cichlidae) of Kivu lake in Central Africa. Thesis. KULeuven 271.

9. Ulyel AP, Ollevier F, Ceusters R, This Van Den Audenaerde D (1990) Die of Haplochromis spp (Teleostein: Cichlidae) in Africa 1. Interspecific trophic relationships. Belg J Zool 120: 143-155.

10. Paugy D (1978) Ecology and biology of Alestes baremoza (Pisces characidae) from rivers of Côte d'Ivoire. Cah ORSTOM, sér. Hydrobiol 12: 245-275.

11. Lévêque C, Paugy D (1999) Fish of African continental waters: Diversity, ecology and use by human. (IRD).

12. Chikou A, Huriaux F, Laleye P, Vandewalle P, Focant B (1997) Isoform distribution of parvalbumins and of some myofibrillar proteins in adult and developing Chrysichthys auratus (Geoffroy St. Hilaire, 1808) (Pisces, Claroteidae). Archives of Physiology and Biochemistry 105: 611-617.

13. Biswas SP (1993) Manual of Methods in Fish Biology. Fish Biology \& Ecology Laboratory, Dibrugarh University 60-89.

14. Philippart JC (1975) Dynamic of fish populations no exploited. In: Dynamic of vertebrate populations (Lamotte M, Bourlière F eds). Ed. Masson. Paris 292 394.

15. Legendre $M$, et Jalabert B (1988) Reproduction physiology. In Lévêque C Bruton MN, Scentengo GW éd: Biology and ecology of African freshwater fishes. Paris, Orstom, Travaux et documents, 216: 153- 187.

16. Teugels GG, Guégan JF (1994) Biological diversity of freshwater fishes of lower-Guinea and Central Africa. Annales du Musée Royale d'Afrique Centrale 275: 67-85.

17. Paugy D (1994) Ecology of tropical fish of Baoule temporary stream, upper basin of Senegal in Mali: adaptation to area and plasticity of diet. Rev Hydrobiol trop 27: 157-172.

18. Matthes H (1964) Fish of lake Tumba and Ikela area: systematics and ecology. MRAC N 126, Bruxelles 204.

19. White L, Edwards A (2000) Data analysis and interpretation. In: White, L. and Edwards, A. Conservation in African rainforest: research methods. WCS, New York, Pp 31-52.

20. Mahamba B (2009) Characterization of Mormyridae communities from Yoko and Biaro forest streams: Biology and ecology of Stomatorhinus corneti. Master thesis, University of Kisangani 98.

21. Pigneur LM (2005) Taxonomy of genus Marcusenius (Mormyridae) at pool Malebo in Kinshasa/ DRC and contribution to biological and ecological study of Marcusenius macrolepidotus angolensis. Master thesis, FUNP/Namur 63.

22. Mbimbi MJ (2006) Contribution to biology and ecology of Marcusenius greshoffi (Schilthuis 1891), Master thesis, University of Kinshasa 41.

23. Traoré $A$, Diomandé $D$, Wattara $A$, Gaurène $G$ (2005) Diet of Paraila pellucida (Schilbeidae) from three rivers of côte d'Ivoire, laboratory of environment and aquatic biology, UFR- SGE, University of Abodo- Adjamé, Cybium, revue internationale d'Ichtyologie 29: $\mathrm{N}^{\circ} 4$.

24. Moyle PB, Cech JJ (2004) Fishes: an introduction to ichthyology. 5th ed. ISBN 0-13-100847-1. 637-710.

25. Kirschbaum F (1984) Reproduction of weakly electric teleosts: just another example of convergent development? Env Biol Fish 10: 3-14.

Copyright: (c) 2016 Kankonda AB, et al. This is an open-access article distributed under the terms of the Creative Commons Attribution License, which permits unrestricted use, distribution, and reproduction in any medium, provided the original author and source are credited. 